\title{
PENGARUHGROUP SIZE TERHADAP PENGAMBILAN KEPUTUSAN KELOMPOK
}

\author{
Diah Nurayu Kusumawardani, Joevarian, Nezza Nehemiah, \\ Pramwidya Mazmur Novia, Putu Widiastiti Giri \\ Fakultas Psikologi, Universitas Indonesia \\ Kampus Baru UI - Depok 16424 \\ diahnurayu@gmail.com, joehudijana@gmail.com, \\ rambut.jabrik@hotmail.com,pram.mazmur@gmail.com, \\ putu.widiastiti89@gmail
}

\begin{abstract}
People have to deal with problems on a daily basis. Problems may appear both at the individual level and at the group level. Effective methods to deal with problems become essential. This paper questons 'Does the number of people in a single group matter in effective problem solving? Previous studies have shown inconsistencies of results. This paper aims to find a cause-effect relationship between group size and the effectivity of problem solving wthin the group. There are two types of experimental groups with the total of 16 groups. The first eight consists of 4 people and the latter consists of 8 people within a group. One-tailed hypothesis stated that groups of 4 will perform better than groups of 8 . Every group was given a same case to be solved. While the observed group dynamics differences existed, the results showed that the group of 4 is no better than the groups of 8 in terms of decision making effectivity. The results, will be further discussed.
\end{abstract}

Key word: Group Dynamic, Group Size, Decision Making Effectiveness

\begin{abstract}
Abstrak
Semua orang menghadapi masalah dalam kehidupan sehari-hari yang dapat muncul pada individu maupun kelompok. Metode efektif untuk menyelesaikan masalah menjadi sangat penting. Apakah kemudian jumlah orang dalam kelompok mempengaruhi proses penyelesaian masalah?. Beberapa penelitian sebelumnya menunjukkan hasil yang berbeda-beda. Penelitian ini bertujuan untuk mengetahui hubungan kausal antara variabel
\end{abstract}


group size terhadap pengambilan keputusan kelompok. Ada dua jenis kelompok eksperimen dalam penelitian ini, yaitu kelompok dengan 4 anggota dan kelompok dengan 8 anggota. Hipotesis one-tailed menyatakan bahwa kelompok dengan 4 anggota akan melakukan performa lebih baik daripada kelompok dengan 8 anggota. Setiap grup diberikan kasus yang sama untuk diselesaikan. Meski perbedaan dinamika kelompok memang terjadi, namun hasil menunjukkan bahwa kelompok dengan 4 anggota tidak lebih baik daripada kelompok dengan 8 anggota terkait efektivitas pengambilan keputusan. Hasilnya, didiskusikan lebih lanjut.

Kata Kunci: Dinamika kelompok, Efektivitas pengambilan keputusan, Group Size

\section{Pendahuluan}

Kegiatan mengambil keputusan sering dilakukan oleh individu dalam rutinitasnya dan seolah tidak pernah lepas dari kehidupnya. Individu akan selalu mengambil keputusan untuk mengarahkan kegiatannya selama seharian penuh dari bangun pagi sampai tidur lagi. Bagaimana jika pengambilan keputusan tersebut dilakukan oleh kelompok?. Banyak fenomena yang melibatkan kelompok dalam pengambilan keputusan. Siswa-siswa SMA yang mengikuti OSIS sering terlibat dalam pengambilan keputusan kelompok ketika dihadapkan mengenai suatu masalah. Tidak hanya siswasiswa SMA, para mahasiswa lebih intens terlibat dalam kegiatan pengambilan keputusan kelompok, misalnya dalam rapat kepanitiaan atau tugas kelompok.

Fenomena mengenai pengambilan keputusan dalam kelompok berbeda dengan pengambilan keputusan secara individu. Dalam pengambilan keputusan secara kelompok, pilihan alternatif pengambilan keputusan akan sangat beragam karena semua anggota kelompok akan mengutarakan idenya masing-masing. Hasil dari alternatif pengambilan keputusan akan diproses lebih jauh untuk ditentukan seberapa besar kualitas pengambilan keputusan yang akan diambil kelompok nanti (Kerr \& Tindale, 2004).

Pengambilan keputusan menurut Baron dan Byrne (2008) adalah suatu proses melalui kombinasi individu atau kelompok dan mengintegrasikan informasi yang ada dengan tujuan memilih satu dari berbagai kemungkinan tindakan. Pengambilan keputusan juga didefinisikan oleh Sweeney dan McFarlin (dalam Sarwono \& Meinarno, 2009) sebagai suatu proses mengevaluasi pilihan-pilihan yang ada untuk 
mendapatkan hasil yang diharapkan. Johnson dan Johnson (2006) memberikan definisi group decision making yaitu menemukan kesepakatan di antara anggota kelompok sebagai tindakan yang paling ingin dicapai dalam tujuan kelompok. Decision making dalam kaitannya dengan konteks kelompok, didefinisikan menjadi suatu proses mental yang dilakukan dalam kelompok oleh seluruh anggota kelompok dengan tujuan memilih satu tindakan dari berbagai alternatif pilihan tindakan yang ada sebagai cara mencapai tujuan kelompok.

Penentuan kualitas pengambilan keputusan tidak terlepas dari faktor group size dalam kelompok yang terlibat. Group size didefinisikan oleh Galanes dan Adams (2007) sebagai ukuran atau jumlah anggota dalam kelompok. Semakin besar group size maka semakin heterogen anggota dalam kelompoknya. Aspek heterogenitasnya mencakup kemampuan pada bidang spesifik yang berbeda, informasi dan perspektif dalam proses pengambilan keputusan. Kelompok dengan anggota yang lebih heterogen lebih efektif daripada kelompok dengan anggota yang homogen. Heterogenitas kelompok dapat meningkatkan performa kelompok terutama karena munculnya informasi yang berbeda-beda dari kelompok (Hoevel, Knippenberg, Ginkel, \& Barkema, 2012) sehingga memfasilitasi kemunculan solusi-solusi dalam jumlah besar.

Besarnya group size juga memiliki dampak baik positif maupun negatif. Dampak negatif dari semakin besarnya group size adalah waktu koordinasi yang lebih lama dan energi yang lebih besar dikontribusikan dalam proses pengambilan keputusan kelompok. Kelompok juga lebih sulit untuk mencapai konsensus ketika memutuskan sesuatu. Dampak positif dari meningkatnya group size adalah semakin besarnya kuantitas informasi yang didapatkan sehingga mendorong kreativitas (Hoever, Knippenberg, Ginkel, \& Barkema, 2012).

Hackman dan Vidmar (dalam Margolis, 2011) menemukan bahwa group size yang optimum pada kepuasan kelompok adalah ukuran 4-5 orang dalam kelompok. Penelitian lain yang selaras dengan Morgan, Coates, dan Rebbin (dalam Johnson \& Johnson, 2006) menemukan bahwa performa atau kinerja kelompok semakin meningkat ketika satu anggota dikeluarkan dari kelompok dengan group size 5 orang. Group size berjumlah 4 orang meningkatkan performa kelompok. Penelitian oleh Watson dan Johnson (dalam Johnson \& Johnson, 2006) menemukan bahwa dalam kelompok dengan group size yang lebih besar dari 8 atau 9 jumlah anggotanya, akan ada beberapa anggota yang mendominasi dan lainnya menjadi anggota pasif dalam group decision making. Hal tersebut menunjukkan bahwa group size 4-8 orang memiliki probabilitas lebih besar untuk terjadinya partisipasi aktif anggotanya. 
Baron \& Kerr (2003) menyatakan bahwa kelompok dengan jumlah anggota yang besar akan lebih memiliki anggota-anggota dengan kompetensi yang bervariasi sehingga spesialisasi pengerjaan tugas akan lebih mungkin terjadi. Johnson \& Johnson (2006) menyatakan bahwa ukuran kelompok harus cukup kecil agar sumber daya dalam kelompok benar-benar dimanfaatkan secara keseluruhan dan mudah untuk dikoordinasikan. Jumlah ukuran kelompok yang efektif dalam pengambilan keputusan kelompok sejauh ini masih kontradiktif, oleh karena itu peneliti menggunakan kelompok dengan group size 4 orang dan group size 8 orang sebagai manipulasi penelitian ini untuk menilai efektivitas group decision making.

Jumlah individu yang berperan atau group size yang efektif diyakini memiliki kontribusi terhadap group decision making, peneliti ingin melihat apakah ada perbedaan antara kelompok berjumlah anggota minimal dengan kelompok yang memiliki anggota maksimal. Peneliti menggunakan group size 4 orang sebagai kelompok minimal yang efektif memberikan kesempatan kepada anggota untuk berpartisipasi aktif dalam kelompok, sedangkan group size 8 orang sebagai kelompok maksimal yang efektif memberikan kesempatan kepada anggota untuk berpartisipasi aktif dalam kelompok. Hipotesis dalam penelitian ini adalah ada perbedaan dalam skor efektivitas group decision making antara kelompok partisipan dengan jumlah anggota 4 orang dan kelompok dengan jumlah anggota 8 orang.

\section{Metode Penelitian}

Subjek penelitian ini adalah siswa SMA Labschool Rawamangun. Karakteristik utama subjek penelitian ini adalah siswa dengan intensitas kegiatan kelompok yang tinggi dimana siswa kelas XI SMA Labschool memenuhi kriteria penelitian tersebut. Total pertisipan penelitian ini adalah 112 orang, dengan jumlah jawaban yang dapat diolah sebanyak 96 orang.

Subjek penelitian terdiri atas 68 orang (60.71\%) perempuan dan 44 orang (39.93\%) laki-laki dengan rentang usia antara $14 \mathrm{~s} / \mathrm{d} 17$ tahun. Mayoritas subjek berusia 16 tahun, yaitu sebanyak 62 orang (55.36\%), sedangkan usia termuda subjek dalam penelitian ini adalah 14 tahun sebanyak 1 orang. Berdasarkan suku bangsa, subjek penelitian ini cukup terdiri dari etnis yang beragam, yaitu suku Jawa denganjumlah 51 orang (45.54\%), suku Sunda sebanyak 23 orang (20.54\%), dan sisanya adalah suku diluar Jawa dan Sunda sebanyak 38 orang (33.92\%). Berdasarkan program studi, partisipan subjek tebagi ke dalam dua bagian yaitu IPA dan IPS. Jumlah partisipan yang berasal dari program studi IPA berjumlah 83 orang 
(74.11\%). Sedangkan partisipan yang berasal dari program studi IPS berjumlah 29 orang (25.89\%).

Teknik pengambilan data dalam penelitian ini akan dilakukan dengan selfreport dalam bentuk kuesioner dimana partisipan mengisi penelitian sendiri instrumen penelitian. Alasannya, menggunakan kuesioner adalah lebih mudah dalam melakukan persebaran dan dapat menjangkau partisipan lebih banyak dalam sekali waktu (Kumar, 2005).

Alat ukur yang digunakan dalam penelitian ini adalah kuesioner studi kasus berjudul 'Evakuasi Kapal Bon Jovi’. Dalam studi kasus ini partisipan akan dihadapkan pada suatu situasi cerita penyelamatan dimana mereka diminta menentukan tokohtokoh apa saja yang akan mendapatkan prioritas untuk diselamatkan berdasarkan ranking (ordinal). Jumlah tokoh yang harus diselamatkan sebanyak 11 orang. Pemberian ranking kepada 11 tokoh akan dilakukan dua kali untuk setiap pertisipan yaitu dalam kondisi diskusi kelompok dan secara individual. Durasi pengerjaan diskusi kelompok adalah 15 menit, sedangkan pengerjaan individual selama 5 menit. Penentuan alat ukur dan durasi pengerjaan didapatkan dari hasil pilot study yang dilakukan pada sampel lain yang memiliki karakteristik setara dengan karakteristik partisipan penelitian.

Teori perkembangan moral Kohlberg (dalam King, 2011) menjadi dasar dalam penyusunan alat ukur. Dalam teori moralitas Kohlberg, terdapat tiga tahap perkembangan mengenai cara berpikir moral. Pada setiap tahap, masing-masing memiliki dua tingkatan perkembangan. Tahap pertama (tahap prekonvensional) adalah tahap perkembangan moralitas yang masih didasari pemberian (reward) dan hukuman (punishment) dari dunia eksternal. Tahap ini terdiri dari dua tingkat, yaitu tingkat 1: Heteronomous morality (yang baik adalah jika tidak memberikan konsekuensi negatif), dan tingkat 2: Individualism, Purpose, and Exchange (yang baik adalah jika terjadi hubungan timbal balik). Pada alat ukur, tingkat 1 prekonvensional disimbolkan dengan tokoh polisi dan kapten kapal karena alasan penyelamatan kedua tokoh ini didasari oleh adanya ancaman jika tokoh tidak ditolong. Ancaman merupakan konsekuensi negatif dari dunia eksternal sehingga ini tergolong tingkat 1 prekonvensional. Alasan penyelamatan setiap tokoh dapat dilihat di lampiran. Tokoh C.E.O. dan pengacara diselamatkan karena ada imbalan dari mereka setelah selamat. Imbalan ini merupakan hubungan timbal balik sebagai karakteristik tahap 2 prekonvensional.

Tahap kedua teori moralitas Kohlberg (tahap konvensional) adalah tahap perkembangan moralitas yang mulai menginternalisasi nilai-nilai moral yang dijunjung 
masyarakat. Tahap ini terdiri dari dua tingkat, yaitu tingkat 3: Mutual interpersonal expectations and interpersonal conformity (yang baik adalah jika berbuat untuk orang-orang yang memiliki hubungan baik dengan kita), dan tingkat 4: Social system morality (yang baik adalah jika berbuat berdasarkan aturan yang disepakati bersama). Tokoh teknisi kapal dan wanita karir diselamatkan atas dasar hubungan karib dengan penyelamat (sahabat, penyelamat masa lalu). Artinya, penyelamat dan kedua tokoh memiliki hubungan yang baik sehingga tergolong dalam tingkat 3 tahap konvensional. Selanjutnya, tokoh pemimpin negara dan wartawan digolongkan dalam tingkat 4 dalam tahap ini karena alasan penyelamatannya didasari oleh identitas sebagai warga negara dan peran wartawan sebagai penulis berita. Dasar alasan penyelamatan ini tergolong aturan sistem sosial sehingga tergolong tingkat 4 tahap konvensional.

Terakhir, tahap ketiga teori moralitas Kohlberg (tahap poskonvensional) merupakan tahap munculnya berbagai alternatif moralitas, mempertimbangkan faktor situasional dari keadaan seseorang, dan mengembangkan kode etik universal dari dalam diri. Tahap ini terdiri atas tahap 5: Social contract and individual rights (yang baik adalah jika nilai-nilai dan hak-hak terpenuhi), dan tahap 6: Universal ethical principles (yang baik adalah yang sesuai dengan nilai-nilai kemanusiaan universal). Tokoh rohaniawan dan dokter diselamatkan karena karakteristiknya yang dapat menenangkan dan bisa menyembuhkan penyakit orang yang dievakuasi. Alasan penyelamatan ini terkait dengan adanya pemenuhan nilai rohani dan kesehatan bagi orang yang dievakuasi sebagai karakteristik tingkat 5 tahap poskonvensional.

Tingkat 6 direpresentasikan dengan tokoh ibu mengandung karena jika ibu ini diselamatkan, maka bayi yang dikandung dan dua anak yang ada di Ambon juga terselamatkan sementara suaminya sudah meninggal. Artinya, bukan hanya satu individu yang diselamatkan, tetapi ada 4 individu sekaligus yang tetap dapat melanjutkan kehidupannya setelah selamat. Ini sesuai dengan prinsip etika universal pada tingkat 6 tahap poskonvensional.

Dalam studi kasus ini partisipan akan dihadapkan pada suatu situasi cerita penyelamatan, partisipan nantinya akan diminta menentukan prioritas penyelamatan, dengan menentukan tokoh-tokoh apa saja yang akan mendapatkan prioritas untuk diselamatkan berdasarkan ranking (ordinal) yang berjumlah 11 orang. Pengerjaan soal studi kasus ini akan dilakukan dua kali untuk setiap pertisipan yaitu dalam kondisi diskusi kelompok dan secara individual. Durasi pengerjaan diskusi kelompok adalah 15 menit dan pengerjaan soal secara individual selama 5 menit.

Teknik skoring dalam penelitian ini didasarkan pada rumusan effective decision making Maier (dalam Redhani, 1992), yaitu: 
E. D. $=\mathrm{f}(\mathrm{Q} \times \mathrm{A})$

E. D. $=$ Effective Decision

$\mathrm{Q}=$ Quality

$\mathrm{A}=$ Acceptance

Nilai Quality (Q) didapat dari selisih antara jawaban kelompok dengan kualitas pilihan jawaban dalam studi kasus yang dibuat berdasarkan teori perkembangan moral Kohlberg (dalam King, 2011). Nilai Acceptance (A) didapat dari penjumlahan dari seluruh hasil selisih antara jawaban individu dan jawaban kelompok yang kemudian dibagi dengan jumlah anggota kelompok. Efektivitas keputusan akhir didapat dari jumlah seluruh hasil perkalian Q dan A untuk setiap tokoh dalam kasus. Semakin kecil hasil yang didapatkan, semakin efektif keputusan, dan sebaliknya.

Prosedur penelitian ini dilakukan melalui beberapa tahap. Pertama, tahap persiapan. Tahap persiapan dilakukan menyusun instrumen berupa kuesioner studi kasus berdasarkan instrumen sejenis yang kemudian dimodifikasi. Proses selanjutnya adalah persiapan pelaksanaan pilot study. Proses pilot study dilakukan untuk mendapatkan gambaran umum mengenai kemudahaan peserta dalam membaca soal dan kemenarikan instrumen penelitian yang akan digunakan. Pilot study juga dilakukan untuk mendapatkan gambaran mengenai durasi pelaksanaan penelitian baik untuk diskusi kelompok maupun pengerjaan individual.

Tahap kedua adalah tahap pelaksanaan penelitian. Pelaksanaan eksperimen dalam penelitian ini dijalankan dalam 4 kelas berbeda berdasarkan prosedur penelitian yang dituliskan sebelumnya. Tahap-tahap tersebut meliputi pengisian informed consent, pembentukkan kelompok melalui randomisasi, diskusi dan pengerjaan tugas kelompok, serta pengerjaan tugas individual. Hasil dari pelaksanaan kedua tugas ini kemudian akan dianalisis menggunakan rumus effective decision-making untuk melihat kualitas pengambilan keputusan.

Penelitian ini menggunakan teknik statistik Man-Whitney U-test sebagai teknik analisis data. Teknik statistik ini dipilih terutama karena penelitian ini merupakan penelitian eksperimen dua kelompok. Sedikitnya jumlah partisipan (jumlah kelompok) yang berhasil didapatkan menyebabkan data tidak dapat diolah dengan teknik statistik parametric sehingga data hasil skoring alat ukur yang berupa data ratio akan diubah menjadi data ordinal untuk kemudian diolah berdasarkan ranking yaitu dengan statistik Man-Whitney U-test.

\section{Hasil dan Pembahasan}

Hasil penelitian dapat digambarkan sebagai berikut: 


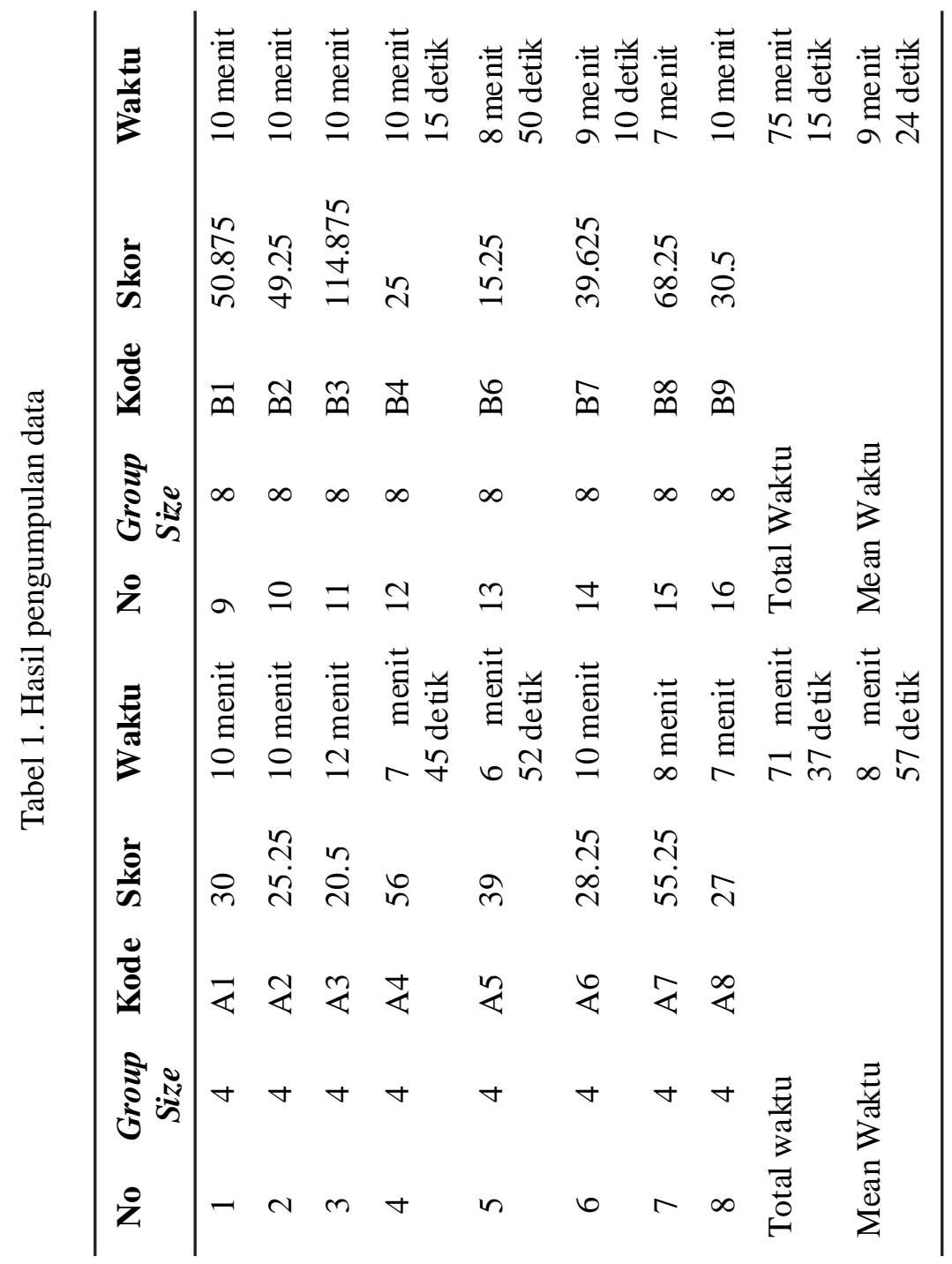


Tabel 1 merupakan rincian waktu pengerjaan tugas diskusi kelompok dari total 16 kelompok yang terdiri dari 8 kelompok dengan group size 4 orang dan 8 kelompok dengan group size 8 orang. Kelompok dengan kode yang dimulai dengan A menandakan bahwa kelompok tersebut ber-group size 4 orang, kelompok yang dimulai dengan kode B menandakan kelompok dengan group size 8 orang. Berdasarkan hasil penelitian, diperoleh nilai rata-rata waktu pengerjaan diskusi 8 kelompok dengan group size 8 orang adalah 9 menit 24 detik dan rata-rata waktu pengerjaan diskusi group size 4 adalah 8 menit 57 detik. Berdasarkan deskripsi tersebut, dapat dikatakan bahwa durasi untuk menyelesaikan tugas dengan group size 4 orang lebih cepat (8 menit 57 detik) dibandingkan durasi kelompok dengan group size 8 orang ( 9 menit 24 detik).

Tabel 2. Tabel statistik deskriptif

\begin{tabular}{llc}
\hline & $\mathbf{N}$ & Nilai rata-rata \\
\hline Decision Making & 16 & 4,22 \\
Group Size & 16 & 1,50 \\
\hline
\end{tabular}

Berdasarkan tabel 2, dapat diketahui bahwa nilai mean skor effective group decision making adalah 4,22. Sedangkan nilai rata-rata group size adalah 1,5. Jumlah partisipan $(\mathrm{N}$ ) adalah 16 . Selanjutnya, tabel 03 menunjukkan skor effective decision making pada masing-masing kelompok.

Tabel 3. Mean rankgroup decision making

Group Decision Making

\begin{tabular}{llc}
\hline Group & $\mathbf{N}$ & Mean Rank \\
\hline 1 & 8 & 7,50 \\
2 & 8 & 9,50 \\
\hline Total & $\mathbf{1 6}$ & \\
\hline
\end{tabular}

Berdasarkan tabel 3, diperoleh hasil skor mean rank efektivitas group decision making kedua kelompok. Kelompok dengan group size 4 orang (group 1) memiliki mean rank sebesar 7,5, sedangkan kelompok dengan group size 8 orang (group 2) memiliki mean rank sebesar 9,5. 
Tabel 4. Hasil pengolahan statistik

Decision Making

\begin{tabular}{lc}
\hline & Decision Making \\
\hline Mann-Whitney U & 24,0000 \\
Z &,- 840 \\
Asymp.Sig.(2-tailed) & 0,401 \\
\hline
\end{tabular}

Setelah diketahui berapa mean rank setiap kelompok group size, maka di tabel 04 ditunjukkan hasil analisa statistik menggunakan tehnik statistik Mann-Whitney test. Terlihat bahwa nilai signifikansinya adalah 0.401 yang lebih besar dari nilai kritisnya (0.05), dengan demikian $\mathrm{H} 0$ gagal ditolak, artinya tidak ada perbedaan yang signifikan dalam skor efektivitas pengambilan keputusan kelommpok antara kelompok partisipan dengan jumlah anggota 4 orang dan kelompok dengan jumlah anggota 8 orang ( $>0.05$, two-tailed test). Akan tetapi, dapat juga signifikansi diterima jika nilai U statistik yang diperoleh sama atau lebih kecil dari nilai tabel Mann-Whitney. Dengan kata lain, hipotesis nol yang berbunyi "tidak ada perbedaan yang signifikan dalam efektivitas group decision making antara kelompok yang beranggotakan empat orang dengan kelompok yang beranggotakan delapan orang”, dinyatakan diterima.

Penelitian-penelitian sebelumnya) menunjukkan inkonsistensi hasil mengenai berapa jumlah anggota kelompok yang dapat mempengaruhi efektivitas pengambilan keputusan kelompok (dalam Johnson \& Johnson, 2006). Oleh karena masih bervariasinya hasil penelitian yang ada sebelumnya, maka prediksi mengenai group zise yang efektif tidak dapat dilakukan oleh peneiti, sehingga peneliti tidak memiliki hipotesis mengenai mana kelompok yang lebih efektif dalam pengambilan keputusan. Hasil menunjukkan bahwa peneliti gagal menolak hipotesis null (Ho). Kegagalan dalam menolak hipotesis null (Ho) menunjukkan bahwa tidak ada perbedaan efektivitas pengambilan keputusan pada kedua kelompok.

Efektivitas pengambilan keputusan dalam kelompok dapat terhambat oleh faktor-faktor penghambat dalam dinamika kelompok (Forsyth, 2010). Terdapat faktor social loafing (yaitu berkurangnya usaha individu dalam kelompok untuk mencapai tujuan kelompok), respon dominan tanpa dikritisi, free riding (yaitu berkurangnya usaha individu dalam menyelesikan tugas kelompok karena individu itu tahu bahwa anggota kelompok lain akan menggantikannya mengerjakan tugas), hilangnya motivasi akibat perasaan tidak adil dalam kelompok, groupthink (yaitu kecenderungan setiap 
anggota untuk menyetujui hasil keputusan padahal keputusan cenderung tidak efektif), dan lain-lain. Pada pelaksanaan diskusi, faktor-faktor tersebut seharusnya muncul dengan intensitas dan frekuensi lebih tinggi pada salah satu kelompok apabila hipotesis awal peneliti terbukti. Hasil penelitian menunjukkan bahwa tidak ada perbedaan ranking pilihan efektivitas yang signifikan pada kelompok yang terdiri dari 4 orang dan kelompok yang terdiri dari 8 orang, sehingga dapat diasumsikan bahwa faktorfaktor penghambat tersebar secara merata baik pada kelompok yang terdiri dari 4 orang maupun 8 orang. Pada kedua kelompok eksperime juga terdapat faktorfaktor pendorong efektivitas pengambilan keputusan, faktor-faktor itu juga tersebar secara merata dikarenakan tidak adanya perbedaan yang signifikan antara kedua kelompok. Dengan demikian, tidak terdapat perbedaan intensitas dan kemunculan faktor-faktor yang menghambat atau mendorong efektivitas keputusan kelompok proses dinamika kelompok pada kelompok yang anggotanya berjumlah 4 orang maupun 8 orang.

Hasil penelitian menunjukkan bahwa tidak ada perbedaan pengambilan keputusan kelompok pada kelompok dengan jumlah anggota 4 orang dan dengan jumlah anggota 8 orang, hal ini sejalan dengan penelitian oleh Watson dan Johnson ( dalam Johnson \& Johnson, 2006) yang menyatakan bahwa kelompok dengan pengambilan keputusan paling efektif berkisar antara 4 orang sampai 8 orang dalam satu kelompok. Kelompok dengan anggota 4 orang maupun dengan anggota 8 orang sama-sama memicu partisipasi aktif dari anggota-anggota kelompok dalam berkontribusi untuk efektivitas keputusan.

Berdasarkan estimasi lamanya waktu diskusi, dapat dikatakan kedua kelompok memliki efektivitas yang sama. Rata-rata waktu yang dibutuhkan oleh kelompok eksperimen 1 (group size 4 orang) dan kelompok eksperimen 2 (group size 8 orang) adalah 8 menit 57 detik dan 9 menit 24 detik. Hal tersebut menunjukkan bahwa tidak ada perbedaan yang besar dalam waktu penyelesaian tugas yang diberikan oleh anggota kelompok.

Beberapa keterbatasan dalam penelitian ini diduga mampu menyebabkan ketidaksesuaian hasil antara penelitian sebelumnya dengan hasil penelitian yang dilakukan oleh peneliti. Banyak confounding variable yang pada akhirnya tidak dikontrol oleh peneliti. Confounding variable adalah variabel eksternal yang dapat mempengaruhi hubungan kedua variabel (Kumar, 2005). Dalam penelitian ini, confounding variable merupkan kondisi waktu penelitian yang berbeda-beda. Peneliti tidak dapat mengontrol confounding variable dengan alasan tidak dimungkinkannya melakukan teknik kontrol konstansi kondisi untuk mengontrol 
variabel waktu partisipan dalam melakukan diskusi kelompok. Dari tiga kali pertemuan dengan partisipan di hari-hari yang berbeda, peneliti melakukan pengambilan data saat hari Kamis pagi jam 10.15, Jum'at dan Rabu siang jam 13.15 dan Senin siang jam 14.45. Selain dari efek-efek perbedaan kondisi yang disebabkan perbedaan waktu, terdapat juga masalah konsentrasi yang tidak sama antar kelompok dengan waktu pengerjaan yang berbeda. Pada pagi hari, asumsi peneliti konsentrasi siswasiswa terhadap tugas yang diberikan lebih baik daripada konsentrasi siswa-siswa yang diberikan tugas pada siang hari. Oleh karena perbedaan tingkat konsentrasi itu, peneliti asumsikan juga terdapat perbedaan tingkat motivasi. Motivasi siswa dalam mengerjakan tugas lebih rendah pada siang hari dengan konsentrasi yang lebih rendah dibandingkan dengan motivasi siswa pada pagi hari dengan konsentrasi yang lebih tinggi. Asumsi ini cukup diperkuat dengan bervariasinya skor yang didapatkan dari kelompok-kelompok dengan hari yang berbeda dan waktu berbeda.

Salah satu variabel eksternal yang juga sangat tidak mungkin dikontrol oleh peneliti tetapi mungkin saja memengaruhi hasil adalah kebisingan ruangan yang berasal dari luar ruangan maupun yang berasal dari partisipan lainnya dalam kelas. Tiap partisipan mungkin mendengar diskusi dari kelompok lain dalam satu kelas yang sama. Variabel eksternal yang peneliti anggap cukup mengganggu adalah interaksi dengan siswa lain di luar kelas. Sekali dan dua kali dan terutama pada pilot study, terdapat beberapa siswa yang tidak diikutsertakan dalam penelitian dan berada di luar kelas secara tiba-tiba masuk ke dalam ruangan kelas yang digunakan dalam penelitian. Mereka secara bebas berinteraksi dengan partisipan penelitian, hal tersebut juga diasumsikan dapat membuat kelompok partisipan terganggu saat melakukan diskusi sehingga efektivitas group decision making menurun.

Kebeterbatasan penelitian juga bisa ditinjau dari kasus yang digunakan oleh peneliti dalam mengukur respon dari partisipan. Kasus yang digunakan oleh peneliti adalah kasus yang dibuat sendiri oleh peneliti berdasarkan teori moralitas dari Lawrence Kohlberg (dalam King, 2011) yang digabungkan dengan teori Utilitarianisme dari filsafat Etika. Peneliti mengakui bahwa proses menentukan kualitas pengambilan keputusan tidaklah berasal dari hasil konstruksi alat ukur secara kuantitatif yang telah teruji validitas dan reliabilitasnya. Peneliti mengkonstruksi alat ukur ini lebih secara kualitatif. Peneliti juga mendasarkan konstruksi alat ukur baik dari segi bahasa maupun dari segi teoretis lebih secara asumtif. Jika efektivitas tidak mampu terukur dari kasus ini, maka skor keseluruhan yang didapat dari partisipan tidaklah mengukur apa yang seharusnya diukur. 


\section{Simpulan}

Berdasarkan hasil penelitian, dapat disimpulkan tidak ada pengaruh group size terhadap efektivitas group decision making. Variasi group size dalam kelompok dengan group size 4 orang dan kelompok dengan group size 8 orang ditemukan tidak berbeda secara signifikan dalam efektivitas group decision making.

\section{Daftar Pustaka}

Baron, R.A., Branscombe, N.R., \& Byrne, D. (2008). Social psychology, $12^{\text {th }}$ Ed. Boston, MA: Pearson Education.

Baron, R. S., Kerr, N. L. (2003). Group Process, Group Decision, Group Action (2nd Ed.). Philadelphia: Mcgraw-hill.

Forsyth, D.R. (2010). Group Dynamics, $5^{\text {th }}$ Ed. Belmont: Wadsworth.

Galanes, G.J., Adams, K. (2007). Effective Group Discussion: Theory and Practice (12 ${ }^{\text {nd }}$ Ed.). New York: McGraw-Hill Companies.

Hoever, I.J., Knippenberg, D., Ginkel, W.P., Barkema, H.G. (2012). Fostering team creativity: Perspective taking as key to unlocking diversity's potential. Journal of Applied Psychology, 97, 5, 982-996. 10.1037/a0029159.

Johnson, D.W., Johnson, F.P. (2006). Joining Together: Group Theory and Group Skills ( $9^{\text {th }}$ Ed.). Needham Heights, MA: A Pearson Education Company.

Kerr, N.L., \& Tindale, R.S. (2004). Group Performance and Decision Making. Annual review of psychology. 55: 623-55.

King, L. (2011). The science of psychology: An appreciative view, $2^{\text {nd }} \mathrm{Ed}$. New York, NY: McGraw-Hill.

Kumar, R. (2005). Research methodology: a step-by-step guide for beginners (2nd Ed.).London: Sage.

Margolis, S.L. (2011).’What is the optimal group size for decision- making?’. http:/ /www.sheilamargolis.com/2011/01/24/what-is-the-optimal-group-size-fordecision-making/.

Redhani, C. (1992).Pengaruh Gaya Manajemen Pemimpin Kelompok Terhadap Efektivitas Keputusan Kelompok. Skripsi: Universitas Indonesia. 
Sarwono, Sarlito W., Meinarno, Eko A. (2009). Psikologi Sosial. Jakarta: Salemba Humanika. 